\title{
Prevalence of hypertension in mid adolescents in central India: A school based comparative study
}

\author{
Sharma $\mathbf{R}^{1}$, Mandliya $\mathbf{J}^{2}$, Dhaneria $\mathbf{M}^{2}$, Tiwari $\mathbf{H ~ L}^{2}$ \\ ${ }^{1}$ Dr Roop Sharma, MBBS, MD, Fellow, Sir Ganga Ram Hospital, New Delhi, ${ }^{2}$ Dr Jagdish Mandliya*, Associate \\ Professor , ${ }^{3}$ Dr Mamta Dhaneria*, Professor, ${ }^{2}$ Dr H.L Tiwari*, Professor. *All are affiliated with Department of Peiatrics, \\ RD Gardi Medical College, Ujjain, MP, India
}

Address for correspondence: Dr. Roop Sharma, Email: roopksharma@gmail.com

\begin{abstract}
Introduction: Hypertension among children and adolescents has increased significantly in the developed countries during the past two decades and similar trends are being observed even in the developing world. Methods: Mid adolescent boys and girls (14-16years) of three government and four private schools of Ujjain city were included with sample size of 1000. A pre designed questionnaire regarding nutritional and dietary history was prepared with measurement of anthropometry. Results: The overall prevalence of pre-hypertension and hypertension children in our study is $6.8 \%$ and $8.2 \%$ respectively, where as worldwide prevalence of hypertension is $7 \%$ to $19 \%$. The prevalence of systolic pre-hypertension and systolic hypertension in children of government schools (14-16 yrs) was 7.5\% and 8.5\% respectively. In private schools out of 75 hypertensive students $49(65.3 \%)(\mathrm{p}=0.06)$ were consuming excess calorie. The incidence of systolic hypertension was low in the students with physical, activity $\geq 1 \mathrm{hr} /$ day and it was observed that both TV watching and Computer use were not associated with hypertension. Conclusion The prevalence of systolic hypertension in boys was higher in private schools as compared to government $(7.8 \%>5.9 \%)$. Girls were more hypertensive in government as compared to private schools $(12.4 \%>7.9 \%)$. Various factors which were found to have correlation with hypertension include calorie intake, number of meals per day, lack of physical activity in the present study.
\end{abstract}

Keywords: Adolescent hypertension, Systolic and Diastolic hypertension.

\section{Introduction}

The World Health Organization (WHO) describes overweight obesity and hypertension as one of today's most important public health problems, which is escalating as a global epidemic [1]. It is also increasingly recognized as a significant problem in developing countries and countries undergoing economic transition [2]. The importance of hypertension in the pediatric population has not been as well appreciated as in adults. Children with elevated blood pressure (BP) can develop target organ damage [3], and they are also at increased risk of cardiovascular disease in adulthood [4]. Consequently, detection and management of elevated BP at an early age may be an important means for limiting the disease burden due to hypertension [5]. The prevalence of hypertension

Manuscript received: $4^{\text {th }}$ June 2014

Reviewed: $10^{\text {th }}$ June 2014

Author Corrected: $17^{\text {th }}$ June 2014

Accepted for Publication: $20^{\text {th }}$ June 2014

International Journal of Medical Research and Review among children in several recently conducted studies in Western countries ranged from 7 to $19 \%$ [6]. However, few studies have been conducted in children in developing countries.

A study of blood pressure levels among primary school students in Kuwait found that the overall prevalence of hypertension was $5.1 \%, 3.6 \%$ among school children in Jordan [7], and $4.30 \%$ among preparatory school children in Alexandria [8].

The prevalence of childhood obesity has increased markedly over the last 2 decades [9]. This increase is associated with an increase in hypertension rates which could lead to atherosclerotic disease in adulthood $[6,10]$

Primary hypertension in children has become increasingly common in association with other

Available online at: www.ijmrr.in 891 | P a g e 
cardiovascular risk factors that include being overweight, insulin resistance, and dyslipidemia [6].

Many studies have shown that increased blood pressure is associated with being overweight in children and adolescents of Western countries $[6,11,12]$.

However, few data are available in non-Western countries and in non-Caucasian populations [13,14,15].

Previous studies [16-18] reported ethnic variation in the relationship of overweight/obesity and change in blood pressure, and this ethnic variations could be either genetic or environmental or both.

Thus, the aims of the present study were to estimate the prevalence of hypertension, and obesity \& to investigate the relationship between BP and different body parameters.

Though several studies have been conducted from different parts of our country to evaluate the prevalence of obesity and hypertension, very few studies have been done from central part of India.

So we planned a school based observational study to detect the prevalence of obesity and hypertension among adolescents of Ujjain city.

\section{Materials and Methods}

Study subjects: School going mid adolescent boys and girls of age group 14-16 yrs from government and private schools of Ujjain city.

\section{Inclusion criteria.}

a. Age group 14-16 yrs.

b. The students and the school administration should give written consent.

\section{Exclusion criteria}

a. The students having systemic illnesses.

b. The students having congenital malformations.

\section{Sample Size}

a. 1000 students.

b. 466 from private schools.

c. 534 from government schools.

\section{Material used}

a. Weighing machine

b. Measuring tape (metallic)

\section{c. Sphygmomanometer (Manual)}

5. Method: A pre designed questionnaire / proforma including information regarding demographic details (name, age, gender, address, religion, parental education, parental occupation), family history of chronic diseases (Hypertension, diabetes mellitus, ischemic heart disease, cerebro-vascular accidents and other chronic illness if any), dietary habits \& pattern of eating (e.g.-eating of junk food, habits of snaking, eating in front TV etc.) and level of physical activity etc.

6. Sampling: The current study was conducted in three government and four private schools of Ujjain city of Madhya Pradesh. School was used as the main sampling unit task. Of all the schools in the region, three government and four private schools were randomly selected.

A total sample of 1000 children (466 from government and 534 from private school), volunteered to participate in the study were included in study. Children's parents or guardians were fully informed about the objectives and methods of the study and signed a consent form.

The study protocol was approved by the Ethical committee of R.D Gardi Medical College and the school management

7. Measurement technique: BP was measured using the standardized mercury sphygmomanometer with manually inflated cuff of suitable size and a stethoscope. It was measured on the right arm after the child was sitting quietly for 5 minutes to relieve anxiety, and seated with his or her back supported, feet on the floor, right arm supported, and cubital fossa at heart level of left arm.

Two readings were obtained at a 2 -min. interval, and the average was recorded. A third reading was taken when BP was found elevated and then average was taken. The mean of three values of blood pressure were measured and corrected for age and sex in the form of centile bands and compared with US National Childhood Blood Pressure standards [19]. The blood pressure percentiles were determined accordingly:

1. When the BP was greater than the 90th percentile for age, gender, and height.

2. If BP was greater than the 95th percentile, BP was staged to stage I (95th percentile to the 99th percentile plus $5 \mathrm{mmHg}$ ).

Available online at: www.ijmrr.in 892 | P a g e 
3. If B.P was greater than $>99$ th percentile plus 5 $\mathrm{mmHg}$ it was labeled as stage 2 [19]

4. Average SBP or BP levels that are greater than or equal to the 90th percentile, but less than the 95th percentile, had been designated as "high normal" and were considered to be an indication of heightened risk for developing hypertension.

8. Data collection: Study period extended from October 2009 to June 2011.

\section{Anthropometric measurements}

a) Weight was measured using a spring balance with an accuracy of $\pm 50 \mathrm{~g}$. Subjects were weighed without shoes. b) Height was also measured to the nearest $0.1 \mathrm{~cm}$ with the use of measurement scale put against the wall. Height was measured without shoes and with children keeping their shoulders in a relaxed position, their arms hanging freely and their head aligned in Frankfurt plane.

c) BMI was calculated by dividing weight $(\mathrm{kg})$ by height squared $\left(\mathrm{m}^{2}\right)$.

Formula:-Weight $(\mathrm{kg}) \div$ height $\left(\mathrm{m}^{2}\right)$.

Participants were classified as 'underweight', 'normal', 'overweight' and 'obese', according to the WHO ageand sex-specific BMI cutoff points [20].

\section{Results}

Table- 1: shows Age and gender wise distribution of study subjects in government and private schools

\begin{tabular}{|l|l|l|l|l|l|l|l|l|}
\hline \multirow{2}{*}{$\begin{array}{l}\text { Age } \\
(\text { years })\end{array}$} & \multicolumn{3}{|c|}{ Government } & \multicolumn{3}{c|}{ Private } \\
\cline { 2 - 9 } & Boys(n) & $(\%)$ & Girls(N) & $(\%)$ & Boys(n) & $(\%)$ & Girls(N) & $(\%)$ \\
\hline 14 & 103 & 37.87 & 57 & 29.38 & 97 & 33.00 & 85 & 35.42 \\
\hline 15 & 101 & 37.13 & 70 & 36.08 & 114 & 38.78 & 70 & 29.17 \\
\hline 16 & 68 & 25.00 & 67 & 34.54 & 83 & 28.23 & 85 & 35.42 \\
\hline Total & 272 & 100 & 194 & 100 & 294 & 100 & 240 & 100 \\
\hline
\end{tabular}

Table- 2: Mean \pm SD of Mean BP of students of government and private school

\begin{tabular}{|c|c|c|c|c|c|c|c|c|c|}
\hline \multirow[b]{2}{*}{$\begin{array}{l}\text { Age } \\
\text { (years) }\end{array}$} & \multicolumn{4}{|c|}{ Government } & \multicolumn{5}{|c|}{ Private } \\
\hline & $\begin{array}{l}\text { Boys } \\
\text { Mean } \\
\text { B.P }\end{array}$ & $\pm S D$ & $\begin{array}{l}\text { Girls } \\
\text { Mean } \\
\text { B.P }\end{array}$ & $\pm S D$ & $\begin{array}{l}\text { Boys } \\
\text { Mean } \\
\text { B.P }\end{array}$ & $\pm S D$ & $\begin{array}{l}\text { Girls } \\
\text { Mean } \\
\text { B.P }\end{array}$ & $\pm S D$ & $\begin{array}{c}\mathrm{P} \\
\text { value }\end{array}$ \\
\hline 14 & 76.23 & 7.00 & 78.78 & 5.78 & 80.38 & 8.22 & 83.32 & 6.36 & 0.00 \\
\hline 15 & 81.92 & 8.74 & 81.90 & 6.65 & 80.22 & 7.29 & 81.73 & 7.09 & 0.16 \\
\hline 16 & 87.39 & 8.40 & 82.84 & 7.32 & 80.86 & 8.52 & 79.14 & 7.12 & 0.00 \\
\hline
\end{tabular}


The above table shows that average mean B.P is higher in private schools than in government schools with a significant $p$ value by independent $\mathrm{t}$ test in $14 \mathrm{yr}$ and $16 \mathrm{yr}$ age group which is statistically significant according to independent $\mathrm{t}$ test In $15 \mathrm{yr}$ age group the values are more or less similar. B.P increases with age in males.

Table- 3.1: Prevalence of systolic hypertension in study group

\begin{tabular}{|c|c|c|c|c|c|c|c|c|}
\hline \multirow[t]{2}{*}{ Blood pressul'e } & \multicolumn{4}{|c|}{ Government } & \multicolumn{4}{|c|}{ Private } \\
\hline & $\begin{array}{c}\text { Boys } \\
\mathbb{1}\end{array}$ & $(\%)$ & $\begin{array}{l}\text { Gills } \\
\mathrm{N}\end{array}$ & $(\%)$ & $\begin{array}{c}\text { Boys } \\
\text { II }\end{array}$ & $(\%)$ & $\begin{array}{l}\text { Gills } \\
\mathrm{M}\end{array}$ & $(\%)$ \\
\hline Normal & 234 & 860 & 157 & 80.9 & 257 & 87.4 & 202 & 84.2 \\
\hline Preliypertension & 22 & 8.1 & 13 & 6.7 & 14 & 4.8 & 19 & 7.9 \\
\hline Hypertension & 16 & 59 & 24 & 12.4 & 23 & 78 & 19 & 7.9 \\
\hline Total & 272 & 100 & 194 & 100 & 294 & 100 & 240 & 100 \\
\hline
\end{tabular}

Above table shows prevalence of systolic pre-hypertension and hypertension students in government and private schools

Table 3.2 Prevalence of diastolic hypertension in study group

\begin{tabular}{|l|l|l|l|l|l|l|l|l|}
\hline \multirow{2}{*}{ Blood pressure } & \multicolumn{4}{|c|}{ Government } & \multicolumn{3}{c|}{ Private } \\
\cline { 2 - 10 } & $\begin{array}{c}\text { Boys } \\
\mathbf{n}\end{array}$ & $\begin{array}{c}(\%) \\
\text { Girls }\end{array}$ & $\begin{array}{c}(\%) \\
\mathrm{N}\end{array}$ & $\begin{array}{c}\text { Boys } \\
\mathbf{n}\end{array}$ & $\begin{array}{c}(\%) \\
\text { Girls } \\
\mathrm{N}\end{array}$ & $(\%)$ \\
\hline Normal & 247 & 90.8 & 186 & 95.9 & 269 & 91.5 & 223 & 92.9 \\
\hline Prehypertension & 14 & 5.1 & 8 & 4.1 & 13 & 4.4 & 11 & 4.6 \\
\hline Hypertension & 11 & 4.0 & 0 & 0 & 12 & 4.1 & 6 & 2.5 \\
\hline Total & 272 & 100 & 194 & 100 & 294 & 100 & 240 & 100 \\
\hline
\end{tabular}

Above table shows distribution of diastolic pre-hypertension and hypertension students in government and private schools

Table 4.1 Mean S.B.P. in the normal and overweight group 


\begin{tabular}{|c|c|c|c|c|c|c|c|c|c|}
\hline \multirow{2}{*}{\multicolumn{2}{|c|}{$\begin{array}{l}\text { Age } \\
\text { (years) }\end{array}$}} & \multicolumn{4}{|c|}{ Government } & \multicolumn{4}{|l|}{ Private } \\
\hline & & \multirow{2}{*}{$\begin{array}{l}\text { Boys } \\
\text { Mean BP } \\
105.38\end{array}$} & \multirow{2}{*}{$\begin{array}{l} \pm \text { S.D } \\
9.96\end{array}$} & \multirow{2}{*}{$\begin{array}{l}\text { Girls } \\
\text { Mean BP } \\
106.67\end{array}$} & \multirow[t]{2}{*}{ $\pm S . D$} & \multirow{2}{*}{$\begin{array}{l}\text { Boys } \\
\text { Mean BP } \\
109.72\end{array}$} & \multirow{2}{*}{\begin{tabular}{|l|} 
土S.D \\
9.40 \\
\end{tabular}} & \multirow{2}{*}{$\begin{array}{l}\text { Girls } \\
\text { Mean BP } \\
112.66\end{array}$} & \multirow{2}{*}{$\begin{array}{l} \pm S . D \\
8.35\end{array}$} \\
\hline 14 & No & & & & & & & & \\
\hline & OB & 113.33 & 13.23 & 126.67 & 15.06 & 132.00 & 7.89 & 121.33 & 10.91 \\
\hline \multirow[t]{2}{*}{15} & No & 110.73 & 10.72 & 110.41 & 11.02 & 111.98 & 9.11 & 113.00 & 11.27 \\
\hline & $\mathrm{OB}$ & 120.00 & .00 & 125.82 & 8.36 & 114.67 & 13.14 & 116.13 & 11.23 \\
\hline \multirow[t]{2}{*}{16} & No & 117.26 & 11.25 & 112.68 & 11.75 & 111.16 & 13.74 & 108.50 & 10.08 \\
\hline & $O B$ & 139.00 & 1.10 & 132.80 & 6.57 & 110.00 & 11.55 & 112.00 & 16.43 \\
\hline
\end{tabular}

The above tables show that mean systolic B.P is higher in obese students than normal weight students in $14,15 \& 16$ years of age group, with statistically significant $\mathrm{p}$ value $=0$, by independent $t$ test.

Table- 4.2: Mean D.B.P. in the normal and overweight group

\begin{tabular}{|c|c|c|c|c|c|c|c|c|c|}
\hline \multirow{2}{*}{\multicolumn{2}{|c|}{$\begin{array}{l}\text { Age } \\
\text { (Years) }\end{array}$}} & \multicolumn{4}{|c|}{ Government } & \multicolumn{4}{|c|}{ Private } \\
\hline & & \multirow{2}{*}{$\begin{array}{l}\text { Boys } \\
\text { Mean BP } \\
60.79\end{array}$} & \multirow{2}{*}{$\begin{array}{l} \pm \text { S.D } \\
7.33\end{array}$} & \multirow{2}{*}{\begin{tabular}{|l} 
Girls \\
Mean BP \\
63.25
\end{tabular}} & \multirow{2}{*}{$\begin{array}{l} \pm \text { S.D } \\
5.07\end{array}$} & \multirow{2}{*}{$\begin{array}{l}\text { Boys } \\
\text { Mean BP } \\
64.30\end{array}$} & \multirow{2}{*}{$\begin{array}{l} \pm \text { S.D } \\
9.09\end{array}$} & \multirow{2}{*}{$\begin{array}{l}\text { Girls } \\
\text { Mean BP } \\
67.58\end{array}$} & \multirow{2}{*}{\begin{tabular}{|l} 
S.D \\
6.28
\end{tabular}} \\
\hline 14 & NW & & & & & & & & \\
\hline & OW & 66.67 & 5.00 & 68.33 & 4.08 & 66.80 & 6.05 & 73.33 & 8.12 \\
\hline \multirow[t]{2}{*}{15} & NW & 67.37 & 9.44 & 66.27 & 6.67 & 64.56 & 7.32 & 66.74 & 8.11 \\
\hline & OW & 70.00 & 14.14 & 67.27 & 4.67 & 62.00 & 9.88 & 62.38 & 7.38 \\
\hline \multirow[t]{2}{*}{16} & NW & 70.29 & 7.28 & 67.16 & 6.96 & 65.52 & 9.32 & 64.20 & 7.26 \\
\hline & OW & 84.00 & 10.95 & 67.20 & 9.86 & 70.00 & 11.55 & 66.80 & 7.43 \\
\hline
\end{tabular}

The above tables are showing that mean diastolic B.P is higher in obese students than normal weighted students of 14 , $15 \& 16$ years of age group, with statistically significant $p$ value $<0.05$ by independent $t$ test

Table- 5.1: Prevalence of Systolic hypertension among school adolescents in relation to different parameters of obesity 


\begin{tabular}{|l|l|l|l|l|l|l|}
\hline \multicolumn{2}{|l|}{ Parameters of Obesity } & $\begin{array}{l}\text { Prevalance OF HT } \\
\text { IN Government } \\
\text { n }\end{array}$ & $\mathbf{( \% )}$ & $\begin{array}{l}\text { Prevalance OF HT IN } \\
\text { Private } \\
\mathbf{n}\end{array}$ & $\mathbf{( \% )}$ & P value \\
\hline \multirow{3}{*}{ BMI } & Normal & 55 & 12.8 & 52 & 11.1 & 0.00 \\
\cline { 2 - 6 } & $\begin{array}{l}\text { Over WT/ } \\
\text { OBESE }\end{array}$ & 20 & 51.3 & 23 & 35.4 & \\
\hline WHR & Normal & 58 & 13.3 & 58 & 11.7 & 0.02 \\
\cline { 2 - 6 } & $\begin{array}{l}\text { Over WT/ } \\
\text { OBESE }\end{array}$ & 17 & 5.5 & 17 & 45.9 & \\
\hline WHtR & Normal & 58 & 12.4 & 58 & 11.5 & 0.00 \\
\hline & $\begin{array}{l}\text { Over WT/ } \\
\text { OBESE }\end{array}$ & 17 & 62.9 & 17 & 53.1 & \\
\hline
\end{tabular}

Above table shows prevalence of systolic hypertension in obese students according to different parameters of obesity (statistically significant, $\mathrm{p}<0.05$ ).

Table-5.2: Prevalence of Diastolic hypertension among school adolescents in relation to different parameters of obesity

\begin{tabular}{|c|c|c|c|c|c|c|}
\hline \multicolumn{2}{|c|}{ Parameters of Obesity } & \begin{tabular}{|l} 
Prevalance of HT IN \\
Government \\
$\mathrm{N}$ \\
\end{tabular} & $(\%)$ & $\begin{array}{l}\text { Prevalance of } \mathrm{HT} \text { in } \\
\text { Private } \\
\mathrm{N}\end{array}$ & $(\%)$ & $P$ value \\
\hline \multirow[b]{2}{*}{ BMI } & Normal & 32 & 7.5 & 32 & 6.8 & \multirow[b]{2}{*}{0.012} \\
\hline & $\begin{array}{l}\text { Over WT/ } \\
\text { OBESE }\end{array}$ & 1 & 2.5 & 10 & 15.4 & \\
\hline \multirow[b]{2}{*}{ WHR } & Normal & 33 & 7.6 & 37 & 7.4 & \multirow[b]{2}{*}{0.040} \\
\hline & $\begin{array}{l}\text { Over WT/ } \\
\text { OBESE }\end{array}$ & 0 & 0 & 5 & 13.5 & \\
\hline \multirow[b]{2}{*}{ WHtR } & Normal & 33 & 7.5 & 39 & 7.8 & \multirow[b]{2}{*}{0.117} \\
\hline & $\begin{array}{l}\text { Over WT/ } \\
\text { OBESE }\end{array}$ & 0 & 0 & 3 & 9.4 & \\
\hline
\end{tabular}

Above table shows prevalence of diastolic hypertension in obese students according to different parameters of obesity (statistically significant, $\mathrm{p}=<0.05$ ).

Table- 6: Prevalence of Systolic hypertension in the study group in relation to health behavior 


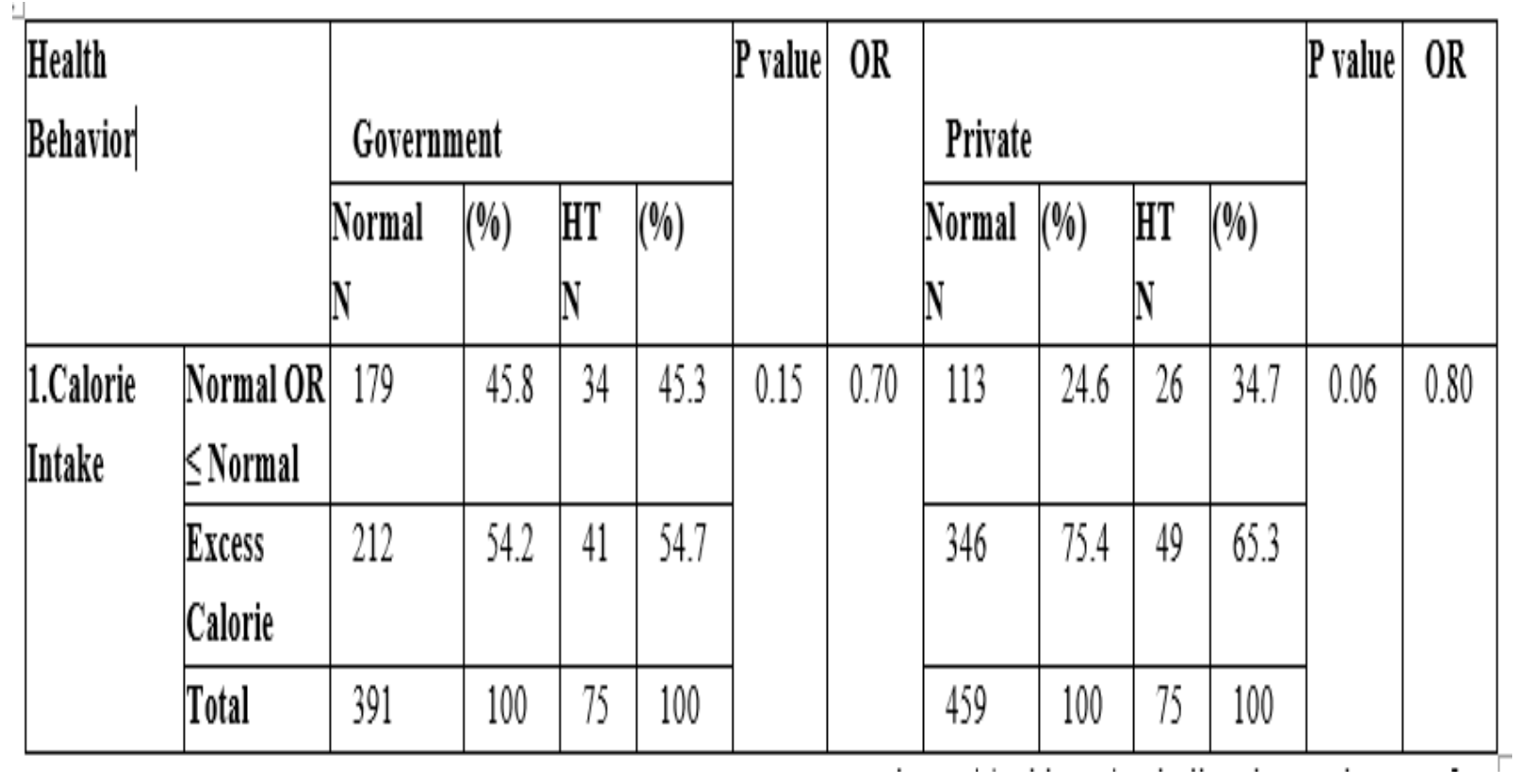

\section{Discussion}

\section{Distribution of students in government and private} schools.

Table 1 Shows age and gender wise distribution of study sample in government and private schools.

There were total 272 boys and 194 girls in the age group of 14-16 years in government school as opposed to 294 boys and 240 girls in private school.

Of the 272 boys there were $103(37.87 \%)$ boys of 14 years age group, $101(37.13 \%)$ of 15 years age group and $68(25 \%)$ of 16 years age group.

Among the girls 57 (29.38\%), 70 (36.08\%), 67 $(34.54 \%)$ were of age group 14, 15, 16 years respectively.

In private schools 97 (33\%), 114 (38.78\%), 83 (28.23\%) boys comprised of study sample in $14,15,16$ years age group respectively as compared to 85 (35.42\%), 70 (29.17\%), 85 (35.42\%) girls.

Prevalence of pre-hypertension and hypertension and its comparison according to age, gender, obesity and school.

In the study age specific mean BP is higher among the private school students than in government school students with a significant $\mathrm{p}$ value in $14 \mathrm{yr}$ and $16 \mathrm{yr}$ age group with is stated in Table 2.

While the mean BP was more or less similar in 15 year age group in both government and private school.
Mean B.P is higher in 16 year age group as the mean height was also higher in this age group, and height is directly proportional to the blood pressure. The blood pressure values increased with age and in boys [21].

In our study the prevalence of pre-hypertension was almost equal in government and private schools $(7.5 \%$ and $6.2 \%)$ (Table 3.1 ).

Similar observation was found by Fernando Antonio de Almeida et al [22] (15.8\% in government and $16.9 \%$ in private). $8.1 \%$ of boys and $6.7 \%$ of girls of government school showed pre-hypertension as compared to $4.8 \%$ of boys and $7.9 \%$ girls in private schools.

This shows that prevalence of hypertension was more among girls in private schools, which is found to be similar with Fernando Antonio de Almeida et al [22] study.

The prevalence of systolic hypertension was $8.5 \%$ and $7.9 \%$ in government and private schools respectively, which is almost equal and is statistically significant $(p=0.00)$.

Whereas $5.9 \%$ boys and $12.4 \%$ of girls in government as compared to $7.8 \%$ boys and $7.9 \%$ girls in private schools showed systolic hypertension.

The prevalence of Systolic hypertension among boys and girls is almost equal in private schools. In 
government school prevalence was higher in girls which is statistically significant $(\mathrm{p}=<0.05)$.

This was also seen in the study by PD Angelopoulos et al [23], Manuraj et al [24].

The observations found in the study by Israeli $\mathrm{E}$ et al [25] showed that gender difference is present and girls are found to be more hypertensive. In Salma B galal et al [26] study no difference was present in prevalence of hypertension regarding both the sexes.

Fernando Antonio de Almeida et al [22] observed there was no difference in prevalence of hypertension in government and private schools. More studies are required to understand the factors related to prevalence of hypertension in both sexes.

The prevalence of diastolic pre-hypertension and hypertension $5.1 \%$ of boys and $4.1 \%$ of girls showed diastolic pre-hypertension in government schools, while $4.4 \%$ of boys and $4.6 \%$ of girls showed diastolic prehypertension in private schools. (Table 3.2).

Prevalence of Diastolic Hypertension among boys is similar in private schools $4 \%$ and $4.1 \%$ in government schools respectively, While $2.5 \%$ girls showed diastolic hypertension in private schools and none in government $(\mathrm{p}=0.03)$.

The prevalence of diastolic hypertension is higher in private than government $(3.8 \%>2.7 \%)$ which was similar to PD Angelopoulos et al[23](16.8\% $>15.9 \%)$, although the prevalence was lower in our study.

In our study more boys were found to be hypertensive than girls in both government and private schools, contrary to Salma B galal et al [26] study who found equal prevalence. More studies are required to understand the difference of observation in our study with Salma et al [26].

\section{Correlation of obesity and hypertension}

The systolic B.P was found to be higher in obese students than normal weight students in $14,15 \& 16$ years of age group, with statistically significant $\mathrm{p}$ value $=0$, by independent $\mathrm{t}$ test(Table 4.1 ).

Our findings are similar to the findings of Manu et al [24]. Our study shows that in 15 year age group obese children have higher systolic B.P than non obese. There is a positive correlation between obesity and mean systolic hypertension as shown by our study Manuraj et al [24].

Similarly mean diastolic B.P was higher in obese students than non obese students in $14,15 \& 16$ years of age group, with statistically significant $p$ value $=0$, by independent $t$ test as shown in (Table 4.2).

Our findings are similar of the findings to the Manu et al [24]. There is a positive correlation between obesity and mean diastolic hypertension as shown by our study.

Table 5.1 shows the correlation between systolic hypertension in government and private school students with different parameters of obesity. $51.3 \%$ of obese students (according to BMI) in government schools and $35.4 \%$ in private schools were having systolic hypertension which was significantly higher $(\mathrm{p}=0.00)$ than students with systolic hypertension of government and private schools of normal weight groups $12.8 \%$ and $11.1 \%$ respectively.

In relation to WHR where $45.9 \%$ of obese students in private and $5.5 \%$ in government were having systolic hypertension which was higher than $11.7 \%$ of private students with hypertension but were of normal weight group, $(\mathrm{p}<0.05)$.

In relation to WHtR similar observations was found, $62.9 \%$ obese students of government school and 53.1 $\%$ of private were having systolic hypertension which was higher than normal weight group students with systolic hypertension of government (12.4\%) and private $(11.5 \%)$ schools,$(p=0.00)$.

Prevalence of hypertension in the obese students according to the BMI is more than according to WHR and WHtR in our study similarly observed by Mostafa et al [27].

But the prevalence of hypertension was same according to WHR and WHtR in our study.

Table 5.2 shows the correlation between diastolic hypertension in government and private schools students with different parameters of obesity. $2.5 \%$ of obese students (according to BMI) in government schools and $15.4 \%$ in private schools were having systolic hypertension which was significantly higher $(p=0.00)$ than students with systolic hypertension of government and private schools of normal weight groups $7.5 \%$ and $6.8 \%$ respectively.

Available online at: www.ijmrr.in 898 | P a g e 
The values are statistically significant $(p=0.012) \chi^{2}$ test. There were no obese students according WHR,WHtR who were hypertensive in government schools.

In private school students $13.5 \%$ obese children (according to WHR) and 9.4\% (according to WHtR) were having diastolic hypertension, which was much higher than students of normal weight group according to WHR and WHtR (7.4\% and 7.8\%) with diastolic hypertension respectively, values were statistically significant $(\mathrm{p}=0.04)$ it correlates diastolic hypertension with central obesity which is also found by Mostafa et al [27] in his study.

The WHtR of all 33 students with diastolic hypertension were normal in government school, while $3(7.1 \%)$ out of 42 students were obese according to WHtR in private schools. But data was not statistically significant.

\section{Behavioral risk factors associated with systolic and diastolic hypertension.}

Table 6 shows effects of health behavior over systolic hypertension like: Calorie intake- regarding calorie intake of 391 governments students 212 (54.2\%) were taking excess calorie but were non hypertensive as compared to $346(75.4 \%)$ out of 459 non obese children consuming excess calorie of private school.

Out 75 students with systolic hypertension children in government schools $41(54.7 \%)(p=0.15)$ were taking excess calorie while $34(45.3 \%$ ) were taking normal or below normal calorie.

Similarly in private schools out of 75 hypertensive students $49(65.3 \%)(\mathrm{p}=0.06)$ were consuming excess calorie and $26(34.7 \%)$ were taking normal or below normal calorie. In both the cases values were statistically insignificant by $\chi^{2}$ test with $\mathrm{OR}=0.70,95 \%$ $\mathrm{CI}=0.426-1.150$ in government schools which is less than private which was $\mathrm{OR}=0.615,95 \% \mathrm{CI}=0.366$ 1.036 .

Therefore it can be said that there is no correlation of high calorie and hypertension and is similar to the findings of PD Angelopoulos et al [23], but the prevalence of systolic hypertension is more in private schools as other factors also play important role in the same.

\section{Conclusions}

International Journal of Medical Research and Review
1. The overall prevalence of pre-hypertension and hypertension children in our study is $6.8 \%$ and $8.2 \%$ respectively, where as worldwide prevalence of hypertension is $7 \%$ to $19 \%$.

2. The prevalence of systolic pre-hypertension and systolic hypertension in children of government schools (14-16 yrs) was $7.5 \%$ and $8.5 \%$ respectively.

3. The prevalence of systolic pre-hypertension and systolic hypertension in children of private schools (14$16 \mathrm{yrs}$ ) was $6.1 \%$ and $7.8 \%$ respectively.

4. The prevalence of systolic hypertension in boys was higher in private schools as compared to government $(7.8 \%>5.9 \%)$. Girls were more hypertensive in government as compared to private $(12.4 \%>7.9 \%)$.

5. The overall prevalence of diastolic hypertension in boys was more or less equal in private and government schools $(4.1 \% \approx 4.0 \%)$. Girls were more hypertensive in government as compared to private $(2.5 \%>0 \%)$.

6. A significant positive correlation is seen between obesity and hypertension.

7. Out of the various factors which were studied, total calorie intake was significantly correlated with prevalence of hypertension was:

8. Our study could have been more specific if we could have included the amount of salt intake and consumption of junk food per day causing hypertension.

9. There was significant correlation found between children who were obese according to BMI, WHR, WHtR and were having systolic or diastolic hypertension.

10. As our study is the only study done to understand prevalence of hypertension in adolescents of Ujjain city, we cannot predict whether the prevalence is increasing or not.

Funding: Nil

Conflict of interest: Nil

Permission from IRB: Yes

\section{References}

1. Must A, Jacques PF, Dallal GE, Bajema CJ, Dietz WH. Long-term morbidity and mortality of overweight

Available online at: www.ijmrr.in 899 | P a g e 
adolescents. A follow-up of the Harvard Growth Study of 1922 to 1935. N Engl J Med. 1992 Nov 5;327(19):1350-5.

2. Abbott RA, Davies PS. Habitual physical activity and physical their relation to body activity intensity: oldchildren. Eur J Clin Nutr. 2004 Feb;58(2):285-91.

3. Lande MB, Carson NL, Roy J, Meagher CC. Effects of childhood primary hypertension on carotid intima media thickness: a matched controlled study. Hypertension. 2006 Jul;48(1):40-4. Epub 2006 May 30.

4. Must A, Jacques PF, Dallal GE, Bajema CJ, Dietz WH. Long-term morbidity and mortality of overweight adolescents. A follow-up of the Harvard Growth Study of 1922 to 1935. N Engl J Med. 1992 Nov 5;327(19):1350-5.

5. Labarthe DR. Prevention of cardiovascular risk factors in the first place. Prev Med. 1999 Dec;29(6 Pt 2):S72-8.

6. Sorof JM, Lai D, Turner J, Poffenbarger T, Portman RJ. Overweight, ethnicity, and the prevalence of hypertension in school-aged children. Pediatrics. 2004 Mar;113(3 Pt 1):475-82.

7. Jaddou HY, Bateiha AM, Khawaldeh AM, Goussous YM, Ajlouni KM. Blood pressure profile in schoolchildren and adolescents in Jordan. Ann Saudi Med. 2001 Jan-Mar;21(1-2):123-6.

8. O. Darwish, A. El Ghamry, M. Hussein, and S. Omara, "Prevalence and some etiological factors of hypertension in school children," Bulletin High Institute of Public Health, vol. 15, no. 3, pp. 97-110, 1985.

9. Bundred P, Kitchiner D, Buchan I. Prevalence of overweight and obese children between 1989 and 1998: population based series of cross sectional studies. BMJ. 2001 Feb 10;322(7282):326-8.

10. Ribeiro J, Guerra S, Pinto A, Oliveira J, Duarte J, Mota J. Overweight and obesity in children and adolescents: relationship with blood pressure, and physical activity.
11. Ebbeling CB, Pawlak DB, Ludwig DS. Childhood obesity: public-health crisis, common sense cure. Lancet. 2002 Aug 10;360(9331):473-82.

12. Genovesi S, Giussani M, Pieruzzi F, Vigorita F, Arcovio C, Cavuto S, Stella A. Results of blood pressure screening in a population of school-aged children in the province of Milan: role of overweight. J Hypertens. 2005 Mar;23(3):493-7.

13. Agyemang C, Redekop WK, Owusu-Dabo $\mathrm{E}$, Bruijnzeels MA. Blood pressure patterns in rural, semi-urban and urban children in the Ashanti region of Ghana, West Africa. BMC Public Health. 2005 Nov $1 ; 5: 114$.

14. Monyeki KD, Kemper HC, Makgae PJ. The association of fat patterning with blood pressure in rural South African children: the Ellisras Longitudinal Growth and Health Study. Int J Epidemiol. 2006 Feb;35(1):114-20. Epub 2005 Oct 31.

15. Jafar TH, Islam M, Poulter N, Hatcher J, Schmid $\mathrm{CH}$, Levey AS, Chaturvedi N. Children in South Asia have higher body mass-adjusted blood pressure levels than white children in the United States: a comparative study. Circulation. 2005 Mar 15;111(10):1291-7.

16. Ke L, Brock KE, Cant RV, Li Y, Morrell SL. The relationship between obesity and blood pressure differs by ethnicity in Sydney school children. Am J Hypertens. 2009 Jan;22(1):52-8. doi: 10.1038/ajh.2008.308. Epub 2008 Nov 6.

17. He Q, Ding ZY, Fong DY, Karlberg J. Blood pressure is associated with body mass index in both normal and obese children. Hypertension. 2000 Aug;36(2):165-70.

18. Sung RY, Yu CC, Choi KC, McManus A, Li AM, Xu SL, Chan D, Lo AF, Chan JC, Fok TF. Waist circumference and body mass index in Chinese children: cutoff values for predicting cardiovascular risk factors. Int J Obes (Lond). 2007 Mar;31(3):550-8. Epub 2006 Sep 5.

19. Falkner B, Daniels SR. Summary of the Fourth Report on the Diagnosis, Evaluation, and Treatment of High Blood Pressure in Children and Adolescents. Hypertension. 2004 Oct;44(4):387-8. Epub 2004 Sep 7. 
20. Giammattei J, Blix G, Marshak HH, Wollitzer AO, Pettitt DJ. Television watching and soft drink consumption: associations with obesity in 11- to 13year-old schoolchildren. Arch Pediatr Adolesc Med. 2003 Sep;157(9):882-6.

21. E. Irgll', Y. Erkenci', N. AytekJn", H. Aytekin' 1 Uludag University Medical School, Department of Publk Health. Buna. Turkey ed 29 May 1999

22. de Almeida FA, Konigsfeld HP, Machado LM, Canadas AF, Issa EY, Giordano RH, Cadaval RA. Assessment of social and economic influences on blood pressure of adolescents in public and private schools: an epidemiological study. J Bras Nefrol. 2011 AprJun;33(2):142-9.

23. Angelopoulos PD, Milionis HJ, Moschonis G, Manios Y. Relations between obesity and hypertension: preliminary data from a cross-sectional study in primary schoolchildren: the children study. Eur J Clin Nutr. 2006 Oct;60(10):1226-34. Epub 2006 May 17.
24. Manu Raj, K. R. Sundaram, Mary Paul, A. S. Deepa, R. Krishna Kumar. Obesity in Indian children: Time trends and relationship with hypertension. The National Medical Journal of India 2007;20(6): 288293.

25. Israeli E, Schochat $\mathrm{T}$, Korzets $\mathrm{Z}$, Tekes-Manova D, Bernheim J, Golan E. Prehypertension and obesity in adolescents: a population study. Am J Hypertens. 2006 Jul;19(7):708-12.

26. Galal SB, Fahmy SA, Lashine S, Abdel-Fattah N, Galal MO. Systemic hypertension and associated factors in school adolescents. International Journal of Collaborative Research on Internal Medicine \& Public Health. 2011; 3 (2):167-176.

27. Abolfotouh MA, Sallam SA, Mohammed MS, Loutfy AA, Hasab AA. Prevalence of elevated blood pressure and association with obesity in egyptian school adolescents. Int J Hypertens. 2011 Mar 8;2011:952537. doi: 10.4061/2011/952537.

\section{How to cite this article?}

Sharma R, Mandliya J, Dhaneria M, Tiwari H L. Prevalence of hypertension in mid adolescents in central India: A school based comparative study. Int J Med Res Rev 2015;3(8):891-901. doi: 10.17511/ijmrr.2015.i8.167. 